\title{
Performance of different provenances and of the local population of the Monterey pine (Pinus radiata D Don) in northern Spain
}

\author{
S Espinel, A Aragonés, E Ritter \\ CIMA, Apartado 46, 01080 Vitoria-Gasteiz, Spain
}

(Received 22 February 1994; accepted 13 April 1995)

\begin{abstract}
Summary - The performances of 3 Pinus radiata provenances, composed of different subprovenances, and of the local population were compared in a completely randomized design in a 4-year trial at Onyi Mountain (Basque country, northern Spain). Significant differences between populations were observed for the growth characteristics. The Monterey population showed the best performance, although a considerable degree of variation among subprovenances was present. Unfavorable climatical conditions in the winter of 1992/1993 caused high mortality rates in the provenances of Monterey and Cambria, while the Año Nuevo population and the local population were less affected. Based on the comparison of growth characteristics, mortality and morphological characters, Año Nuevo seems to be the possible origin of the local Basque population.
\end{abstract}

Pinus radiata / provenance / performance / morphological character / frost resistance

Résumé - Performances comparées de différentes provenances de Pinus radiata D Don et d'une population locale au nord de l'Espagne. Les performances de 3 provenances de Pinus radiata composées par différents sub-provenances ont été comparées avec une population locale à la montagne d'Onyi (Pays Basque, nord de l'Espagne) dans un essai randomisé pendant 4 ans. On a trouvé des différences significatives pour les caractéristiques de croissance entre les populations étudiées. La population Monterey a montré les meilleures performances malgré les variations entre sub-provenances. Les mauvaises conditions climatiques pendant l'hiver 1992/1993 ont été la cause de la mortalité élevée des populations Monterey et Cambria, tandis que les populations Año Nuevo et locale ont été moins affectées. Sur la base de la comparaison de croissance, mortalité et caractéristiques morphologiques, l'origine de la population locale basque peut être la population Año Nuevo.

Pinus radiata / provenance / comportement / caractéristique morphologique / résistance au froid 


\section{INTRODUCTION}

Before introducing tree species into a specific new environment or at the beginning of local breeding programs, provenance tests are quite common to determine their potential value (Shelbourne et al, 1979; Eldridge, 1983; Zobel and Talbert, 1984; Burdon et al, 1992a).

The Monterey pine (Pinus radiata D Don) is the tree species of greatest economic interest in the Basque country in northern Spain (162.000 ha). This species was first introduced at the end of the last century followed by a second introduction in the 1920 s. A breeding program for this species has been established recently and one of the first steps of this program consisted of comparing the growth and morphological characteristics of the local population and that of the natural populations from California, the natural occurrence of Pinus radiata.

\section{MATERIALS AND METHODS}

The plant material used in this field trial consisted of seed samples from 3 provenances (Año Nuevo, PI; Monterey, PII; Cambria, PIII) of the natural populations from California (Eldridge, 1983; Moran et al, 1988) and of a bulked seed sample from the Basque population (PB). This population represents a homogenous one since cones from many locations are collected, dried at one main point and the seeds then redistributed again. The 3 populations of California were composed of several subprovenances formed by stands based on ecological and environmental criteria as defined by Eldridge (1983) and following the same nomenclature. Provenance I, II and III consisted of 4,6 and 3 subprovenances, respectively. Seed material from these natural populations was obtained from the CSIRO Collection (1978).

One hundred seeds of each subprovenance and of the local population were sown in containers in the greenhouse in February 1989. In May 1990 , uniform seedlings of the 14 populations were planted in a completely randomized design with 5 tree plots and 8 repetitions at Onyi Mountain (Guipuzcoa, northern Spain) leading to a total of 560 seedlings (initial spacing $2.5 \mathrm{~m} \times 2.5$ $\mathrm{m})$.

The heights of all the trees in this trial were determined annually. The 1st measurement was taken in October $1990(\mathrm{H} 1)$, the 2nd at the end of September 1991 (H2), the 3rd in October 1992 $(\mathrm{H} 3)$ and the 4th in October $1993(\mathrm{H} 4)$, so that these measurements represent the heights of 1-, 2,- 3- and 4-year-old trees in the field, respectively. Annual growth increments were computed for each period as differences between the corresponding annual heights.

In winter 1992/1993, severe cold and remarkable temperature variations occurred and 143 of the young trees died. In February 1993 in particular, the temperature decreased from 17 to $-7.5^{\circ} \mathrm{C}$ within 8 days. The mortality was recorded for each subpopulation in June 1993. Some morphological needle characters were measured in 10 random samples of entire fascicles of mature needles from 5 different trees of each subprovenance and of the local population collected in autumn 1992. Traits recorded for the needle fascicles were needle length and total number of stomata on a $5 \mathrm{~mm}$ long section in the middle of the needle (Eguiluz, 1984). In addition, the weight of 100 seeds and the cotyledon number of the seedlings were determined.

Statistical analyses were performed with the SAS program package. Specifically, PROC GLM was used taking into account only the population effect in the model for analyses of variance and Fisher's LSD test for the comparison of means.

\section{RESULTS}

Highly significant population effects were found for each annual height in the analysis of variance. Table la shows the average annual heights of the trees of each population and subpopulation. Provenance II showed the highest average tree heights in every year, which differed significantly from all the others in the first 2 years. The lowest average heights were always recorded for Provenance $\mathrm{I}$, which were significantly lower in the 3rd and 4th year. The heights of the local population PB always fell between those of PII and PIII. These tendencies were 
also visible on the level of subpopulations with respect to the maximum values, although a considerable degree of variation between the average annual heights within the subpopulations of each population was present. Subpopulation II/1 showed a remarkably poor performance throughout all of the years with respect to the other subpopulations of Provenance II.

Table Ib shows the average annual growth increments for each year and each population and subpopulation. Provenance I always had the lowest growth increments. Provenance II showed the highest ones only in the vegetative period $1991 / 1992$, but would have always had the highest increments if the unfavorable subpopulation II/ 1 had been excluded. The local population showed intermediate growth increments between those of PI and those of other populations, depending on the year. The growth increments in the period 1992/1993 were generally much lower than in the other periods, since the climatical conditions were unfavorable.

The observed mortalities in 1992/1993 are presented for each population and subpopulation in table Ic. The significantly highest mortalities of over $50 \%$ were observed for the population PIII followed by PII with nearly $30 \%$. Provenance I and the local population $\mathrm{PB}$ were considerably less affected by these climatical conditions and showed no significant differences in mortality. However, the local population had the lowest mortality with only $2.8 \%$. The average values of the morphological needle characters, of the seed weights and of the cotyledon numbers are presented in table II. Significant differences between populations were found for all traits. The highest average values for the needle length and the stomata number were found for population P1 and the local population of the Basque country. The Monterey population had the significantly lowest seed weight and the lowest average number of cotyledons.

\section{DISCUSSION}

Significant differences were found for growth characteristics, as well as for some morphological characters, between the different Pinus radiata provenances and the local population in our trial. Performances of the provenances have also been compared in different trials in other countries, showing a considerable degree of variability in the ranking. As in our trial, Provenance I (Año Nuevo) showed the lowest growth in New Zealand (Burdon et al, 1992b). While the Monterey population also had the highest growth in South Africa (Falkenhagen, 1991), the Cambria population outgrew all other provenances in New Zealand.

Bourdon et al (1992b) stated that the Año Nuevo provenance seemed to be more resistant to cold than the Monterey one, and that the Cambria population was the most sensitive, which is consistent with our results. Apparently, the mortality in the natural populations corresponds to their geographical descendance.

The origin of the early introductions into the Basque country could not be determined. A possible relation of the local population with Provenance II from Monterey can be discarded when comparing growth characteristics and morphological characters between these 2 populations. With respect to the annual heights, the local population occupied an intermediate position between those of Provenance I and Provenance III with an apparently closer relationship to population PIII. However, when comparing the mortalities in these populations, it seems evident that the local population descends from the Año Nuevo population (PI). A possible adaptation process can be excluded in this case for the following reason: unfavorable conditions like those of the winter $1992 / 1993$ have occurred frequently in the past. If such high mortalities as observed in the PIII population had occurred, it seems unlikely that this provenance could have 
Table 1. Growth characteristics and mortality during 1993 of Pinus radiata trees from 3 provenances, including subprovenances and the local population of Northern Spain.

a) Average height of the trees $(\mathrm{cm})$

$\begin{array}{lllll}\text { Population } & \mathrm{H} 1 & \mathrm{H} 2 & \mathrm{H} 3 & \mathrm{H} 4 \\ \text { PI } & 53.8^{\mathrm{c}} & 97.4^{\mathrm{c}} & 142.7^{\mathrm{c}} & 172.6^{\mathrm{b}} \\ \text { PB } & 54.7^{\mathrm{bc}} & 104.2^{\mathrm{bc}} & 156.8^{\mathrm{b}} & 189.0^{\mathrm{a}} \\ \text { PIII } & 58.2^{\mathrm{b}} & 107.8^{\mathrm{b}} & 157.8^{\mathrm{ab}} & 197.0^{\mathrm{a}} \\ \text { PII } & 63.2^{\mathrm{a}} & 113.0^{\mathrm{a}} & 164.7^{\mathrm{a}} & 202.8^{\mathrm{a}}\end{array}$

\section{Subprovenances}

$\begin{array}{lrrrr}\mathrm{PI} / 1 & 52.6 & 96.7 & 143.8 & 175.4 \\ \mathrm{PI} / 2 & 53.5 & 98.3 & 148.7 & 178.1 \\ \mathrm{PI} / 3 & 50.5 & 91.1 & 131.0 & 157.8 \\ \mathrm{PI} / 4 & 58.6 & 104.1 & 148.1 & 180.8 \\ \mathrm{PIII/1} & 55.5 & 102.9 & 154.7 & 194.3 \\ \mathrm{PIII} / 2 & 61.3 & 110.7 & 153.5 & 182.0 \\ \mathrm{PIII} / 3 & 57.9 & 109.7 & 164.8 & 212.5 \\ \mathrm{PIII} / 1 & 50.9 & 94.0 & 137.6 & 160.2 \\ \mathrm{PII} / 2 & 59.6 & 109.7 & 164.1 & 208.7 \\ \mathrm{PII} / 3 & 64.7 & 118.2 & 173.1 & 208.7 \\ \mathrm{PIII} / 4 & 71.9 & 122.6 & 177.0 & 211.2 \\ \mathrm{PIII} / 5 & 66.8 & 118.9 & 173.9 & 220.2 \\ \mathrm{PII} / 6 & 63.5 & 112.4 & 160.5 & 193.5 \\ \text { Mean } & 59.0 & 106.9 & 156.2 & 189.5\end{array}$

b) Average annual growth increment of the trees $(\mathrm{cm})$

Population

D1/2

$\mathrm{D} 2 / 3$

$\mathrm{D} 3 / 4$

c) Mortality (\%) ${ }^{*}$

$\begin{array}{lll}\text { PI } & 43.3^{\mathrm{b}} & 44.7^{\mathrm{b}} \\ \text { PB } & 49.2^{\mathrm{a}} & 53.1^{\mathrm{a}} \\ \text { PIII } & 52.2^{\mathrm{a}} & 51.1^{\mathrm{a}} \\ \text { PII } & 50.5^{\mathrm{a}} & 54.6^{\mathrm{a}}\end{array}$

$30.9^{a}$

$8.1^{\mathrm{a}}$

$31.6^{\mathrm{a}}$

$34.8^{\mathrm{a}}$

$2.8^{\mathrm{a}}$

$52.6^{\mathrm{c}}$

$34.3^{a}$

$29.3^{\mathrm{b}}$

\section{Subprovenances}

$\begin{array}{lll}\mathrm{PI} / 1 & 44.5 & 46.2 \\ \mathrm{PI} / 2 & 44.3 & 50.6 \\ \mathrm{PI} / 3 & 40.4 & 39.9 \\ \mathrm{PI} / 4 & 45.4 & 44.0 \\ \mathrm{PIII} / 1 & 47.5 & 50.7 \\ \mathrm{PIII} / 2 & 49.4 & 42.9 \\ \mathrm{PIII} / 3 & 51.8 & 55.1 \\ \mathrm{PII} / 1 & 43.1 & 43.6 \\ \mathrm{PII} / 2 & 49.8 & 54.5 \\ \mathrm{PII} / 3 & 53.5 & 54.9 \\ \mathrm{PII} / 4 & 50.7 & 54.7 \\ \mathrm{PII} / 5 & 52.5 & 54.9 \\ \mathrm{PII} / 6 & 48.9 & 48.7 \\ \text { Mean } & 47.8 & 49.3\end{array}$

$\begin{array}{rr}31.8 & 2.8 \\ 28.2 & 8.3 \\ 28.8 & 7.9 \\ 35.0 & 13.9 \\ 34.5 & 59.5 \\ 29.2 & 51.3 \\ 40.2 & 47.5 \\ 19.7 & 41.2 \\ 37.3 & 18.9 \\ 31.8 & 40.5 \\ 32.7 & 31.6 \\ 43.3 & 10.8 \\ 34.6 & 33.3 \\ 32.9 & 26.5\end{array}$

$\mathrm{H} 1, \mathrm{H} 2, \ldots, \mathrm{H} 4$ = average heights of $1,2, \ldots, 4$-year-old trees; D1/2, D2/3, D3/4 = average height differences between year 1 and 2,2 and 3,3 and 4; * significant differences were established based on transformed values using arc since $\sqrt{ } \mathrm{x}$; means followed by the same letter are not statistically different $(\alpha=0.05)$. 
Table II. Comparison of some morphological characters in different populations of Pinus radiata.

$\begin{array}{lcccc}\text { Population } & \begin{array}{c}\text { Average needle } \\ \text { length }(\mathrm{cm})\end{array} & \begin{array}{c}\text { Stomata } \\ \text { number }\end{array} & \begin{array}{c}100 \text { seed weight } \\ (\mathrm{g})\end{array} & \begin{array}{c}\text { Cotyledon } \\ \text { number }\end{array} \\ \text { Año Nuevo (PI) } & 10.27^{\mathrm{a}} & 350.6^{\mathrm{a}} & 3.23^{\mathrm{a}} & 7.17^{\mathrm{b}} \\ \text { Basque (PB) } & 10.59^{\mathrm{a}} & 326.8^{\mathrm{b}} & 3.47^{\mathrm{a}} & 7.61^{\mathrm{a}} \\ \text { Cambria (PIII) } & 9.22^{\mathrm{b}} & 276.9^{\mathrm{d}} & 3.43^{\mathrm{a}} & 6.89^{\mathrm{b}} \\ \text { Monterey (PII) } & 9.38^{\mathrm{b}} & 293.1^{\mathrm{c}} & 2.42^{\mathrm{b}} & 6.55^{\mathrm{c}}\end{array}$

Means followed by the same letter are not statistically different $(\alpha=0.05)$.

become established in the Basque country. Instead, the improved growth of the local population with respect to PI can be explained by an adaptative process, since seeds for reforestation were taken from well-performing trees adapted to the particular climatological conditions of this region.

The hypothesis that the local population descends from Año Nuevo is also supported by the similarities among $\mathrm{PI}$ and $\mathrm{PB}$ with respect to some important morphological characters (table II). Needle length, stomata numbers and cotyledon numbers of the local population resemble those of $\mathrm{PI}$ more than those of PIII. The increased seed weight of the local population, which shows a closer relationship with the Cambria population, probably results from a selection process towards bigger seeds within the local population.

Excluding the somewhat outstanding subpopulation II/1, the superior growth characteristics of the Monterey population under our environmental conditions are evident. Therefore, it would be beneficial to introduce plant material of this provenance to achieve increased selection success in the local breeding program. The relatively high mortality rates also observed in this provenance and the considerable amount of variation among subprovenances imply a careful selection of the ecological stand to be introduced and an intensive selection process after introduction. Since the present study is limited by the age of the trees and by the lack of different trial sites, further studies are necessary to ensure the obtained results.

\section{REFERENCES}

Burdon RD, Bannister MH, Madgwick HAl, Low CB (1992a) Genetic survey of Pinus radiata. 1. Introduction, description of experiment, and basic methodology. NZ J For Sci 22, 119-137

Burdon RD, Bannister MH, Low CB (1992b) Genetic survey of Pinus radiata. 2. Population comparisons for growth rate, disease resistance, and morphology. NZJ For Sci 22, 138-159

Eguiluz PT (1984) Geographic variation in needles cones and seeds of Pinus tecunumanii in Guatemala. Sivae Genetica 33, 72-79

Eldridge KG (1983) Genetic resources available. In: Radiata pine breeding manual (AC Matheson, AG Brown, eds), Division of Forest Research, CSIRO, Camberra, 3.1-3.15

Falkenhagen ER (1991) Provenance variation in Pinus radiata at. 6 sites in South Africa. Silvae Genetica 40, 41-50

Moran GF, Bell JC, Eldridge KG (1988) The genetic structure and the conservation of the 5 natural populations of Pinus radiata. Can J For Res 18, 506514

Shelbourne CSA, Burdon RD, Bannister MH, Thulin IJ (1979) Choosing the best provenances of radiata pine for forest sites in New Zealand. NZJ For SCi $24,288-300$

Zobel B, Talbert J (1984) Applied forest tree improvement. John Wiley \& Sons, New York 